\title{
PROBLEMA DE LA
}

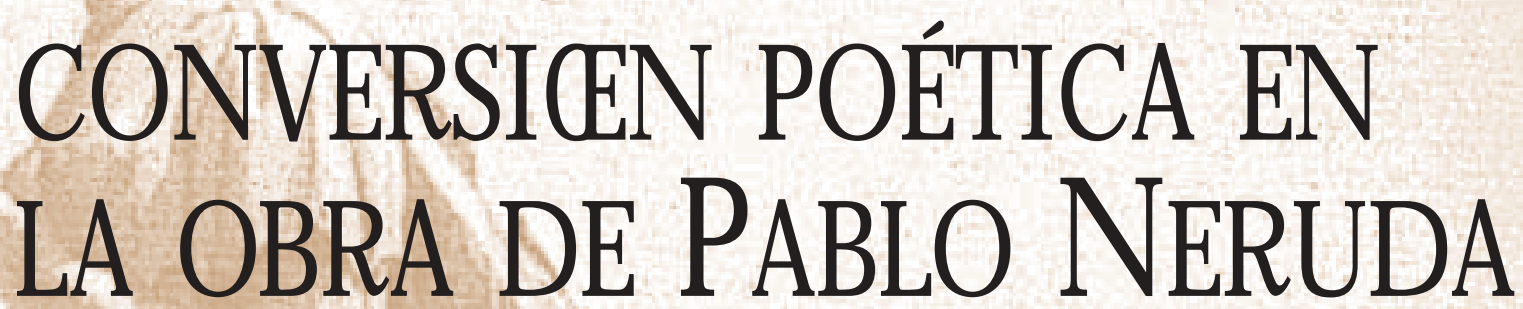

\section{FEDERICO SCHOPF*}

Resumen

El ensayo propone que los cambios notorios en la poesía nerudiana a partir de España en el corazón no se deben a una súbita conversión poética de Neruda, sino a una serie de motivaciones extendidas en el tiempo, según observó ya hace tiempo H. Loyola. Pero estos cambios no pueden comprenderse como una "superación" de su poesía anterior -calificada de meramente subjetiva 0 referida al puro individuo- sino que, en parte, corresponde a cierto voluntarismo poético y, también, a la indagación poética que está en la base de la escritura nerudiana. Incluso la más lograda poesía política de Neruda estaría vinculada a esta indagación poética y no a decisiones ideológicamente dirigidas y poco persuasivas.

Palabras claves: Conversión poética, desarrollo, poesía política, voluntarismo poético, teleología histórica, leyes objetivas de la historia, contradicción.

ABSTRACT

This essay proposes that the notable changes in Neruda's poetry starting with España en el corazón are not due to a sudden poetic conversion on the part of Neruda but to a series of motivations spread over time as $\mathrm{H}$. Loyola has observed in the past. These changes cannot be understood as an "improvement" on his previous poetry - qualified as merely subjective or referring purely to the individual- but rather, in part, they can be attributed to the poetic inquiry that is the basis of Neruda's writing. The most successful of N eruda's political poetry is linked to this poetic inquiry and not to ideologically directed decisions that are not very persuasive.

Keywords: Poetry conversion, development, political poetry, poetic voluntarism, historical teleology, objective laws of the history, contradiction.

Recibido: 01.04.2003. Aprobado: 28.08.2003.

* Poeta y ensayista chileno. Profesor de la Universidad de Chile. Autor de numerosos ensayos sobreliteratura hispanoamericana y sobreproblemas de teoría literaria y arte. Ha publicado, entre otros, Escenas de Peep-show (poesía) y los ensayos La escritura de la semejanza en Nicanor Parra, Del vanguardismo a la antipoesía, Neruda comentado. 
OM O SE sabe, un conocido estudioso de la poesía de N eruda, Amado Alonso -autor del primer libro importante sobre su obra, Poesía y estilo dePablo N eruda, 1940, 2ª ed. 1951, en el que aplica el método estilístico, hasta el momento sólo reservado a obras consagradas históricamente-, comprende el cambio de orientación de la poesía nerudiana, desde la expresión dela "angustia y desintegración" hasta la representación del ser social del hombre, hacia 1937, como una conversión.

Con la idea de que en el poeta nerudiano ha tenido lugar una conversión, apunta Alonso a un acontecimiento psicológicamente análogo al sufrido por San Pablo cuando se le apareció Cristo y se convirtió a su credo. Pero aquí parecería haber terminado la analogía, ya que San Pablo había perseguido hasta ese momento a los cristianos en nombre de la religión romana, en tanto la supuesta conversión de Neruda no consulta persecución al guna, sino queen ella la angustia existencial que predominaría en los poemas de Residencia en la Tierra habría sido bruscamente sustituida -en un acto de revelación- por el descubrimiento del ser social del hombre, que antes no era perseguido o proscrito por el poeta mismo. La conversión es un acto puntual, brusco, no sometido a graduaciones. Alonso afirma que "la poesía de Pablo N eruda ha cambiado dela nochea la mañana radical mente: no más deensimismada soledad, deangustia metafísica y de visión de muerte... desde ahora su poesía es la del hombre con los hombres, encerradas y selladas las angustiosas preguntas que el hombre se hace a solas consigo mismo; una poesía social y de combate político, de adhesión y repulsión para el prójimo, de alegato y execración, de esperanza y rabia: de acción"1.

Para Alonso, el poema en que se manifiesta este cambio radical es "Reunión bajo las nuevas banderas", cuya fecha de escritura no es conocida, pero se estima anterior a 1940. Allí el poeta enfrenta su nueva posición con la anterior y "declara su solidaridad en dolor, en esperanza y en furor, nuevos sentimientos que lo sacan de su 'devoradora noche' de solitario para hacerlo marchar con los hombres"

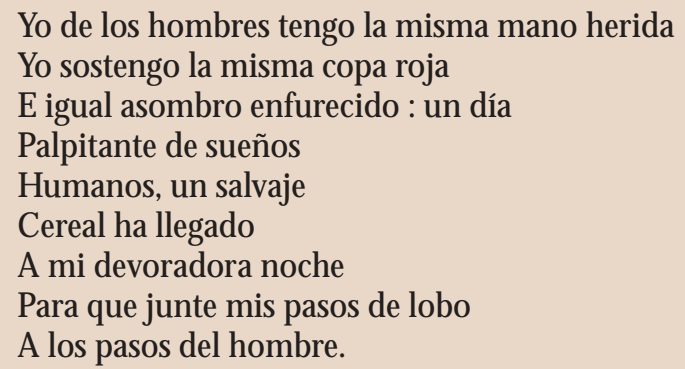

${ }^{1}$ Amado Alonso, Poesía y estilo de Pablo Neruda (1940), B. Aires, Ed. Sudamericana, 1966, $3^{a}$ ed., p. 349.

20 p. cit., p. 350. 
ParaA Ilonso, "ahora nuestro poeta ha puesto sus ojos y su corazón en esa superficie de lo histórico y lo ha hecho centro de su poesía. Y el furor de la pelea de unos hombres contra otros -su propia lucha revolucionaria- tapa y sofoca la angustia del hombre consigo mismo" ${ }^{3}$. En consecuencia con su cambio y descubrimiento del ser social, se dirige ahora no como antes a "al gunos iniciados en los secretos del oficio", sino al pueblo, al artesano, al labriego, al marinero, al obrero, al soldado. También por esta nueva orientación "su poesía se hace clara o por lo menos quiere él hacerla clara"4.

$* * *$

Justamente, Hernán Loyola -en Ser y morir en Pablo Neruda, 1967, su primera interpretación global de la obra nerudiana- comenta este cambio como un desarrollo, y no una conversión puntual, desde "el ángulo éticosubjetivo" a un "plano ético-objetivo", en que el poeta "ha descubierto, para decirlo de una vez, que el Hombre no es sólo naturaleza, sino también historia" ${ }^{\prime \prime}$.

Creo que Loyola ve bien, en el decurso de la poesía nerudiana, al negar queuna conversión súbita estéen la base de los cambios ocurridos en ella en los años en que se desata la Guerra Civil Española, mueren con un breve intervalo sus padres y, al visitar la tumba de ambos, se le ilumina al poeta su relación con su lugar deorigen, La Frontera, y más tarde, al ascender a cabaIlo hasta las ruinas de M acchu-Picchu, descubre no sólo sus raices americanas, sino también -según Loyola- la verdadera muerte, que sería la extinción colectiva de la comunidad quechua y, con ello, la discontinuidad histórica. En este sentido, Loyola sustituye-y subsume- el fundamento puntual que es la poco convincente conversión por la articulación de una serie de experiencias de diverso nivel, multiplicando las motivaciones del cambio e instalándolas en un tiempo relativamente dilatado: 1937-1945 aproximadamente.

Pero Loyola se deja llevar por algunas ilusiones parcialmente compartidas con el poeta -entre ellas, el reconocimiento de leyes objetivas, mecánicamente dialécticas, del desarrollo histórico y la comprensión del arte como un reflejo estético (también mecánicamente dialéctico) de la realidad- en su interpretación de los cambios de la poesía nerudiana de esos años, en especial, de "Alturas de M acchu-Picchu", en que se reflejarían o expresarían estos principios, transformándo a este poema y, en general, a toda la poesía política de Neruda en un medio de comunicación de formas y contenidos anteriores al trabajo material mismo de producción de los poemas.

${ }^{3} 0$ p. cit., pp. 351-352.

${ }^{4} \mathrm{Op}$. cit., p. 352.

${ }^{5}$ Hernán Loyola, Ser y morir en Pablo N eruda, Santiago, Ed.Santiago, 1967, p. 169. 
No es necesario discutir aquí críticamenteel despliegue de esta interpretación de Loyola, sino simplemente citar que, para este estudioso, "experiencias posteriores [de Neruda] , alumbradas por el contacto creciente con el marxismo, lo condujeron a la comprensión integral de que las contradicciones entrela muertey la persecución de una continuidad creadora para su vida, entre la limpidez de lo natural y la inquietante miseria percibida en el ámbito de la convivencia humana, admitían todas ellas la posi bilidad de un camino común y satisfactorio de superación"6.

No cabe duda de que Loyola percibe bien la generación compleja del cambio en la poesía de Neruda, pero le aplica, desde fuera de los textos-tomando en cuenta la biografía oficial de Neruda, que él mismo contribuye a edificar y reduciendo sus experiencias a lo que ilumina la versión partidista de las ideas de $M$ arx- una doctrina exterior y anterior a las formas y contenidos de los textos mismos?.

Siguiendo su tesis, señala Loyola que el mismo año en que "confluye en el poema a Bolívar la univer salidad histórica de las luchas libertarias y progresistas, por un lado, y la percepción específica de la raigal unidad americana", por el otro, la visita deN eruda a M acchu-Picchu (1943) sería "un hecho biográfico que a su vez inspirará un poema decisivo, el poema-síntesis llamado a registrar admirablemente un salto crucial, el momento en que se resuelve el proceso de integración que venía gestándose desde 1937". Para "Alturas de M acchu-Picchu" - repite más adelante- "la clave de su significación radica en el hecho de reflejar el punto culminante de una encrucijada dialéctica, la resolución final de una etapa del proceso interior que venía viviendo Neruda y, al mismo tiempo, la apertura deuna nueva etapa. Balance y rumbo nuevo" .

La "plenitud" - concepto que habría que revisar al margen del contenido que le asigna Loyola en su comprensión paral ela, sin rupturas ni meandros, de ciertas continuidades entre la vida y la obra de Neruda-, esta plenitud

${ }^{6} 0$ p. cit., p. 234-235.

${ }^{7}$ Hay detalles en el libro de Loyola - que no son sólo detalles, sino índices de una posición ideológica- que resultan ahora divertidos: M ola y Franco "desencadenaron el huracán sangriento del fascismo"; el asesinato de García Lorca - "Federico" para Loyola en sintonía sentimental con su vate- "galvanizó a Neruda con un remezón de furia incontenible"; Ios bombardeos de M adrid "Io sitúan de golpeen el corazón del combate". Neruda es "incansableen la lucha política" y en medio de ella la muerte sucesiva de sus padres "ensombreció su entusiasmo combatiente". Más tarde, desde M éxico apoya "Ia heroica lucha del pueblo soviético". Cuando escribe "Canto a Stalingrado", sus versos "testimonian la confianza de Neruda en el triunfo definitivo y la superación de la muerteen la continuidad de la lucha popular". En esos años, "el furioso antifascista marchaba del brazo con el acucioso testigo de la realidad americana y con el enamorado", pero aún no se producía la integración unitaria de sus pluralidades en erupción "en una especie de poeta epico del siglo XX, poeta civil, heroico, portavoz del pueblo y sus luchas, combatiente", etc.

${ }^{8}$ Op. cit., p. 194.

${ }^{9}$ Op. cit., p. 197. 
que se comunicaría en "Alturas de M acchu-Picchu", surgiría, por una parte, desde el acceso gratificante a la comprensión de sí mismo como parte de una colectividad ya desaparecida, que es recuperada escrituralmente por el poeta, lo que le permite superar el hecho dela muerte individual y, por otra, desde la reanudación, lograda por el poeta, de una continuidad de su vida ligada a sus raíces americanas, que también producen una sociedad dividida en clases, a partir de la lectura de sus huellas en las ruinas de la fortal eza incaica. Así, "el camino que Neruda encontró para superar su propia muerte" fuesu perpetuación "en la vida concreta dela comunidad a que pertenecía" ${ }^{10}$. El renacer de la comunidad quechua-desaparecida como efecto de la violencia histórica de la conquista española- se lleva a cabo en la representación de ella que asume el poeta nerudiano en el canto final de las "Alturas de M acchu-Picchu".

Versiones en apariencia menos ortodoxas de este desarrollo fueron publicadas por Loyola a lo largo de los años, hasta culminar en la afirmación sorprendente para esa ortodoxia, para decir lo menos, de que también N eruda, el poeta total - ¡cómo no podría ser!-- habría alcanzado a tener una etapa postmoderna (no vista, claro, por nadie, hasta que se comenzó a hablar de postmodernidad) tratándose, desde luego, para volver a la ortodoxia, de una etapa postmoderna sistemática. Esta etapa habría comenzado ya en 1956, una vez denunciados por Krushev "Ios crímenes de Stalin", revelación a la queN eruda -sumido en "el fin delas ideologías en cuanto motores de la acción histórica"- respondió con "una solemne reafirmación de su ideología comunista"11.

Pero la representación que Loyola tiene de la literatura y sus referencias sigue siendo dependiente de la teoría del reflejo y de la concepción de una dialéctica objetiva dela historia y de la naturaleza, queel poeta iría reflejando creativamente en sus sucesivos textos.

Una muestra de la íntima fidelidad de Loyola a estas ideas - unidas a la discreta arrogancia de sentirse miembro de la élite que conoce las claves de lahistoria- essu afirmación, reiterada en esteprólogo de1971, deque“aquella muerte, la que impregnó de angustia y desconsuelo los versos de Residencia en la Tierra, no erala verdadera M U ERTE. La que cayó sobreM acchu-Picchu, ésa sí... La Muerteno tenía quever con los individuos, sino con los pueblos. La Muerte llegó a M acchu-Picchu no cuando murió Juan Cortapiedras, 0 Juan Comefrío, o Juan Piesdescalzos, sino cuando toda la colectividad desapareció" 12 .

${ }^{10} 0$ p. cit., p. 239.

${ }^{11} \mathrm{H}$. Loyola, "Pablo N eruda. Itinerario de una poesía", en P. Neruda Antología esencial, B. Aires, Ed. Losada, 1971, p. 32. Sobre Neruda posmoderno, vid. Diccionario Encidopédico de las Letras de América Latina, Caracas, Biblioteca Ayacucho, 1988, s.v. Neruda.

${ }^{12} \mathrm{H}$. Loyola, id., pp. 25-26. 
Sorprendentemente -en pleno arrebato de ortodoxia- Loyola, el individuo, continua: "Porque entonces desapareció toda posibilidad de supervivencia para los individuos", a lo que agrega: "Lo que equivale a afirmar, para la vida del hombre, la posibilidad de perpetuarse en la vida concreta de la comunidad a que pertenece. Este fue el camino que N eruda encontró para superar su propia muerte. Allí estaba el terreno propicio que buscaba para fecundar interminablemente su existencia"13.

Desde luego, creo que éste es un desarrollo visible - o que puede hacerse fácilmente visible- en la superficie de la escritura nerudiana y que incluso correspondeal voluntarismo estético asumido por el poeta en los años dela Guerra Fría, tanto por solidaridad emocional como por reflexión crítica o adhesión disciplinada a la doctrina oficial del realismo socialista.

$* * *$

Es denotar que M ario Rodríguez Fernández ya había propuesto algunos años antes un análisis ( 1964) de "Reunión bajo las nuevas banderas", considerado por él un poema clave en el cambio de dirección y temple de ánimo dela poesía nerudiana, en que se expresaba una especie deiluminación profana que habría tenido el poeta, una revelación de su ser social y político sobre la base de la oposición y sustitución entre los rasgos del sujeto residenciario, en especial su alienación, y los rasgos del sujeto que, en este poe ma, proclama el encuentro del otro, la solidaridad y su incorporación a la lucha social, reconociendo como su fundamento la comunidad esencial entre los hombres. Simbólicamente, el poema comenzaría con la imagen de una azucena destruida y concluiría con una flor en plena germinación y belleza ${ }^{14}$.

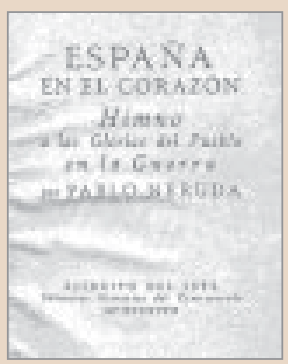

$* * *$

Que desde la experiencia de la Guerra Civil Española y ante la amenaza de la expansión fascista, Neruda - en consonancia con una gran número de escritores durante esos años- haya tomado la decisión de hacer poesía políticamente comprometida , lo muestran no sólo sus abundantes declaraciones en la prensa, sino también su práctica poética misma, uno de cuyos ejemplos más conocidos es este fragmento de España en el corazón (1937):

Preguntaréis: ¿Y dónde están las lilas?

Y la metafísica cubierta de amapolas?

Y la lluvia que a menudo golpeaba

\footnotetext{
${ }^{13}$ H. Loyola, id., p. 26.

${ }^{14}$ M. Rodríguez Fernández, “Reunión bajo las nuevas banderas", M apocho, Santiago, II, 3 (1964), pp. 238-248.
} 
Sus palabras Ilenándolas

De agujeros y pájaros?

... Preguntaréis por qué su poesía

no nos habla del sueño, de las hojas

de los grandes vol canes de su país natal?

Venid a ver la sangre por las calles

Venid a ver

La sangre pos las calles

Venid a ver la sangre

Por las calles! $!^{15}$.

Después de la Segunda Guerra M undial y en plena Guerra Fría, Neruda canta a la Nueva Europa, es decir, a la U nión Soviética y a los países del este europeo, en que se estaría construyendo una nueva sociedad y un hombre nuevo, aceleradamente:

Era una sola claridad

La que despertaba,

La claridad del mundo! ${ }^{16}$.

M ás allá, en la China de la revolución triunfante:

... estaba $M$ ao enseñando

con sus textos

y allí estaba el Partido

con su severidad y su ternura ${ }^{17}$.

Respecto al destino de Rusia:

Entonces en la historia

Vino Lenin

Cambió la tierra

Luego Stalin

Cambió el hombre ${ }^{18}$.

La naturaleza misma está incorporada:

Pasé de noche

Novosibirks, fundada

${ }^{15}$ P. Neruda, España en el corazón, en O bras completas, B. Aires, Ed. Losada, 1962, pp. 254-256.

${ }^{16}$ P. Neruda, Las uvas y el viento, en O.C., p. 679.

${ }^{17}$. Neruda, op. cit., p. 704.

${ }^{18}$ P. Neruda, op. cit., p. 747. 


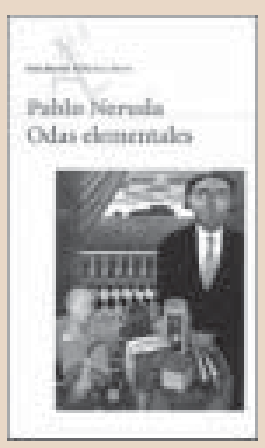

Por la nueva energía.

En la extensión sus luces trabajaban

En medio de la noche, el hombre nuevo

$\mathrm{H}$ aciendo nueva la naturaleza.

Y tú, gran río Yenisey, me dijiste

Con ancha voz, al pasar, tu palabra .

"Ahora no corren en vano mis aguas

Soy sangre de la vida que despierta"19.

Esemismo año, en "El hombreinvisible" - especie de prólogo delas 0 das elementales, 1954-, concluye solicitando :

Dadme

Las luchas

De cada día

Porque ellas son mi canto

Y así andaremosjuntos

Codo a codo

Todos los hombres

M i canto los reúne ${ }^{20}$.

Y en "La casa de las odas" - prólogo, a su vez, de N uevasodas elementales, 1956- aclara el carácter instrumental de su poesía de esta etapa:

Quiero quetodo

Tenga empuñadura

Que todo sea

Taza o herramienta.

Quiero que por la puerta de mis odas

Entre la gente a la ferretería ${ }^{21}$.

Desde esta concepción de la poesía como instrumento de utilidad social, política en el fondo, el poeta representa al ser humano esencialmente como un ser social, superando - diría el propio Neruda en esos años- su propia visión alienada del hombre como un individuo sumido en las angustias de la incomunicación y la muerte, Así, dice

... destroné la negra monarquía

La cabellera inútil de los sueños,

Piséla cola

del reptil mental,

${ }^{19}$ P. Neruda, op. cit., p. 748.

${ }^{20}$. Neruda, O das elementales (1954), en O.C., p. 940.

${ }^{21}$ P. Neruda, Nuevas odas elementales (1956), en O.C., p. 1.130. 
y dispuse las cosas

-agua y fuego-

de acuerdo con el hombre y con la tierra22.

El tono y el mensaje de esta poesía es que la desaparición del ser humano como individuo, su muerte incluso, queda no sólo compensada con la sobrevivencia de la comunidad con que se ha identificado, sino, todavía más, superada o resuelta en su identidad colectiva.

Como se ha visto, en "Reunión bajo las nuevas banderas" ya era reconocida por el poeta la misma "condición herida" con los demás hombres, no por la muerte final -o por la herida originaria dela vida como en la narrativa deKafka o de M anuel Rojas-, sino por la desigual dad social y la explotación económica, quelo impulsa a unirsea los otros y, "duramente central", a luchar y trabajar para alcanzar un porvenir humanamente realizado.

Por esos mismos años-en los inicios de su comprensión colectiva del ser humano, en España en el corazón- expresa que la muerte de los que caen combatiendo estaría negada-ortodoxamente, podría decirsesuperada- por su perduración en la memoria y en la acción de sus compañeros:

No han muerto! Están en medio

Dela pólvora,

De pie, como mechas ardiendo.

Sus sombras puras se han unido

En la pradera de color de cobre

Como una cortina de viento blindado,

Como una barrera defuria,

Como el mismo invisible pecho del cielo23.

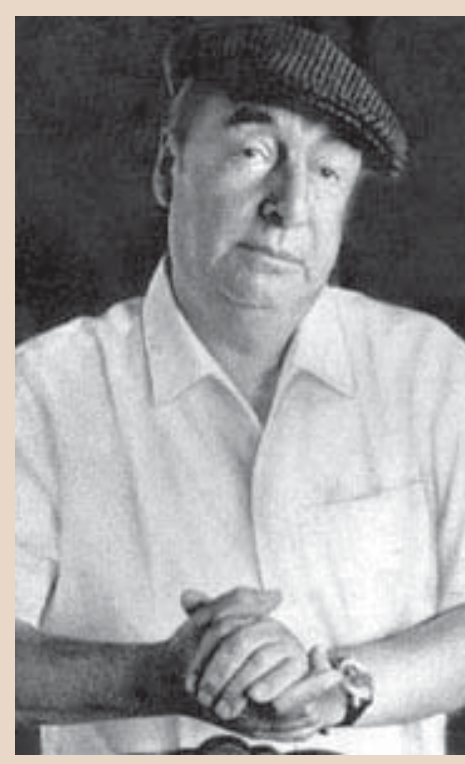

M ás adelante en la misma obra el poeta le dice a los antitanquistas:

Y aquí estáis, preferidos

Hijos de la victoria, muchas veces caídos, muchas veces

Borradas vuestras manos, rotos los más ocultos cartílagos, calladas

Vuestras bocas, machacado

Hasta la destrucción vuestro silencio:

Pero surgís, de pronto, en medio

Del torbellino, otra vez, otros, toda

Vuestra insondable, vuestra quemadora

Raza de corazones y raíces ${ }^{24}$.

22P. Neruda, id. 0.C., pp. 1.129-1.130.

23. Neruda, España en el corazón, en O.C., p. 257.

${ }^{24}$ P. Neruda, id. en O.C., p. 270. 


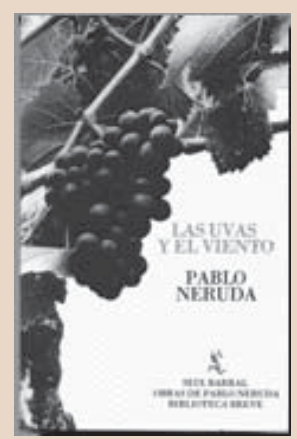

El poeta nerudiano admite y acepta su propia muerte personal - "voy a morir, sin nada más, sin tierra / sobre mi cuerpo, destinado a ser tierra"-, pero simultáneamentecomprende, como partedela plenificación desu vida, que los trabajos y combates de su vida se continúan en "otras manos de agregadafuerza" 25 . Y en su libro siguiente, Lasuvasy el viento, el poeta errante, americano y exiliado representa lleno de admiración el progreso material y humano en los países del este de Europa, agradecido de la época en que le tocó vivir su madurez y participar en la marcha invencible del socialismo.

El fundamento de esta visión de la vida -que se obtiene en el reconocimiento del ser social, solidario, comunicativo, combatiente del hombre- está legitimidado ideológicamente en la doctrina del Partido Comunista Internacional:

Me mostraste cómo el dolor de un ser ha muerto en la victoria de todos

Me enseñaste a dormir en las camas duras de mis hermanos

Me hiciste construir sobre la realidad como sobre una roca.

Me hiciste adversario del malvado y muro del frenético.

Me has hecho ver la claridad del mundo y la posibilidad de la al egría.

Me has hecho indestructible porque contigo no termino en mi mismo ${ }^{26}$.

Una explicitación de esta visión materialista y, en cierto sentido, mecánicamente dialéctica de la vida se encuentra proyectada como una verdadera apoteosis de la continuidad colectiva -en tanto comunicabilidad y superación de la muerte- en el socialismo consumado:

Pero

Del mar

Y dela tierra

Volverán

Algún día

Nuestros muertos

Volverán

Cuando

Nosotros estemos

Verdaderamente

Vivos,

Cuando

El hombre

Despierte

Y los pueblos caminen,

25P. Neruda, Canto general, en O.C., p. 669.

${ }^{26}$ P. Neruda, id. en O.C., p. 674. 
Ellos

Dispersos, solos, confundidos

Con el fuego y el agua,

Ellos

Triturados, quemados,

En tierra o mar, tal vez

Estarán reunidos

Por fin

En nuestra sangre.

Mezquina

Sería la victoria sólo nuestra.

Ella es la victoria final de los caídos²7.

En la misma dirección - pero con más profundidad histórica- se habría movido ya el poeta de "Alturas de M acchu-Picchu" que, ante las ruinas y huellas de la ciudadela incásica, se había proclamado portavoz de la comunidad quechua oprimida por sus señores y desarticulada por la conquista española, llamándola al presente por medio de un patético y grandioso quiasmo:

Acudid a mis venas y a mi boca

$\mathrm{H}$ ablad por mis palabras y mi sangre ${ }^{28}$.

Por cierto, la visión del mundo que expresa N eruda en el nivel más explícito de sus poemas en este período - materialista, mecánicamente dialéctica, objetiva- no se proyecta sólo sobre el presente, sino que se extiende como aparato comprensivo también sobre el pasado y, dentro de él, sobre la obra de algunos poetas que él admira. Así, en la "Oda a don Jorge M anrique" se lee que el poeta medieval hace una especie de autocrítica, en que reconoce que su obsesión con la muerte y su idea de que la verdadera felicidad estaba en la obra vida, se debía al "tiempo oscuro que le tocó vivir". En el presente de Neruda, le parece:

Que no está solo el hombre

En sus manos

Ha elaborado

Como si fuera un duro

Pan, la esperanza,

La terreste

Esperanza ${ }^{29}$.

27P. Neruda, Tercer libro de odas (1957) en O.C., pp. 1.312-1.313.

${ }^{28}$ P. Neruda, "Alturas de M acchu-Picchu", en O.C., p. 324.

${ }^{29}$ P. Neruda, Nuevas odas el ementales, en 0.C., p. 1.212.

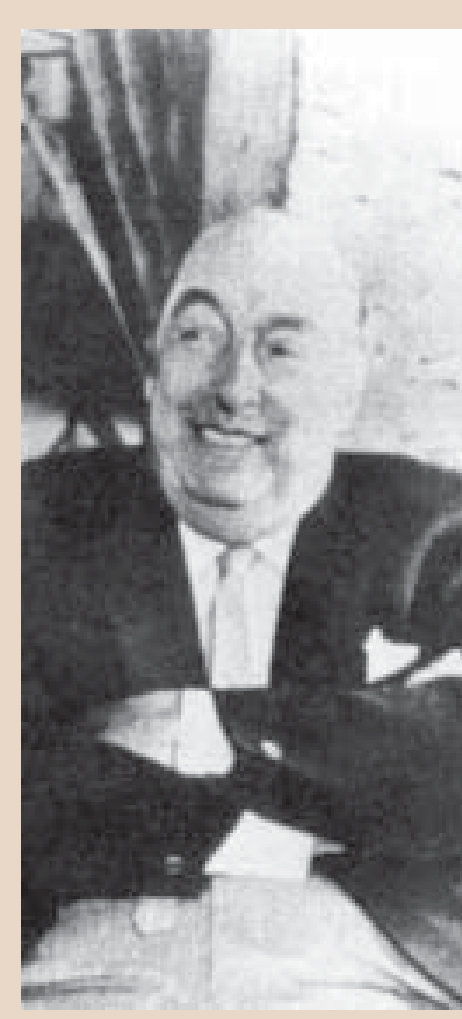


Más claramente aún es la solidaridad surgida en los años en que Neruda escribe la que-según el poeta nerudiano- hubiera podido cambiar la condición y disposición de Rimbaud:

Hoy es más simple, somos
Paises, somos
Pueblos,
Los que garantizamos
El crecimiento de la poesía,
El reparto del pan, el patrimonio
Del olvidado. Ahora
No estarías
Solitario ${ }^{30}$.

$* * *$

Sin embargo, me parece que la afirmada superación del individuo y sus "límites acerados y angustiosos" - como dice Jaime Concha en un eufórico ensayo de 1964- nunca llega a ser completa, en esta etapa de la poesía nerudiana, pese a la voluntad decidida del sujeto poético y a la ideología en que se apoya. Individuo y ser social no se sustituyen absolutamente, no se resuelven o integran totalmente el uno en el otro, no se separan del todo, quedando el uno atrás en el tiempo o restando como un lamentable residuo, sino que más bien se superponen, se recubren parcialmente, esto es, las angustias y anhelos del sujeto individual -a pesar dela decisión del poeta de identificarsesolo o esencialmente con su dimensión social- continúan existiendo subterráneamente, presionan la superficie en apariencia continua de la escritura nerudiana de este período y suelen aflorar perturbando su aparente coherencia, abriendo brechas en el discurso de la voluntad totalizado$\mathrm{ra}^{31}$.

Así -ya desde los inicios de este período- en "Canto sobre unas ruinas" de España en el corazón, la denuncia y lamento inicial de la destrucción de un pueblo por un bombardeo franquista se continúa inesperadamente con el reconocimiento resignado dela temporalidad del ser humano y sus construcciones.

Por cierto, "Canto sobre unas ruinas" no prolonga simplementela tradicional meditación nostálgica sobre los efectos destructivos del tiempo y no despliega el espectáculo de las ruinas de una ciudad históricamente prestigiosa desde la perspectiva de la templada melancolía de un poeta que acepta la condición perecedera de las obras del hombre y del ser humano mismo,

${ }^{30}$ P. Neruda, id. en O.C., pp. 1.244-1.245.

31]. Concha, "El descubrimiento del pueblo en la poesía de Neruda", Aurora, Santiago, 3-4 (1964), p. 132. 
como ocurre en el conocido poema de Rodrigo Caro "A las ruinas de I tálica famosa" que, según muchos críticos, ha servido demodel o al texto deNeruda, está en su base intertextual. Tampoco enumera monumentosfamososy personalidades destacadas del lugar destruido. Por el contrario, la destrucción que se consigna es de data reciente y no ha acumulado huellas de un largo transcurso del tiempo que suavicen o distiendan la continua violencia quela ha originado. Es el resultado de una violencia puntual sobre habitaciones y modestos objetos de uso diario que sehan hecho con largo esfuerzo y trabajo. El contenido comunicado del poema no conduce a la estoica resignación ante la precariedad del ser humano y su obra, sino a la desolación eincluso ira que produce la injusta e inhumana violencia del bombardeo. Desde el punto de vista explícitamente asumido en España en el corazón, la victoria final del pueblo, a corto o a largo plazo - 0 al menos, del Ejército del Pueblo, que "establece los nuevos ojos de la esperanza", así finaliza este libro- , compensará la destrucción y derrota del heroico presente.

Pero - en medio de la enumeración algo caótica de los objetos y materiales destruidos que ha sucedido a la lamentación por su pérdida y la pérdida del trabajo que los ha producido- irrumpe de improviso una secuencia de versos que reinstala la precariedad del fundamento sobre el cual el hombre construye y se sostiene, su breve permanencia, es decir, su temporalidad:

... No hay raíces

Para el hombre: todo descansa apenas

En un temblor de lluvia32.

También en "Alturas de M acchu-Picchu" (1943-1945) de Canto general (1950) restan lugares designificación inquietante o, al menos, diversa o que entran en conflicto con la intención general y totalizadora que preside el poema - 0 , dicho de otro modo, con la dirección más o menos imperativa que trata de darle el poeta- y que parecen no poder integrarse sin dejar residuos importantes u oponer resistencia a la afirmación de la superación dela muerte y la soledad en el descubrimiento del ser social del hombre. La experiencia del ascenso a las ruinas es, como se ha dicho tantas veces, si multáneamente un descenso a las profundidades de la sociedad incásica, que el poeta experimenta como una parte esencial y olvidada de su herencia americana, sus raíces precolombinas. El recorrido de las ruinas o su recuerdo le permite -al través de la lectura de las huellas inscritas en la piedra y en la natural eza que rodea al recinto- el despliegue del esplendor y miseria de la comunidad indígena. El poeta políticamente comprometido se siente llamado a ser el portavoz de la comunidad desaparecida -inmerso en su pre-

32P. Neruda, “España en el corazón”, en O.C., p. 268. 
sente de luchas sociales-, pero también a denunciar que esa grandeza anterior estaba atravesada igualmente por la desigualdad social y la explotación.

Jaime Concha - en un ensayo sobre "El descubrimiento del pueblo en la poesía de Neruda", 1964, inflamado del entusiasmo revolucionario que todavía podía suscitar la situación política deesos años- Ilega a proclamar que "Io quelleva al poeta a sentir en el pueblo la realización plena de lo humano, es su aspecto de totalidad inmortal" 33 . Enseguida, especifica que "extensión y amplitud, condición humilde, clase social, creatividad mediante el trabajo son entonces los rasgos que fijan el rostro multitudinario del pueblo" en este poema ${ }^{34}$, otorgando, así, la base para una comprensión del ser humano como ser social, como una identidad colectiva que se extiende más allá dela muerte personal superándola: “Digamos, por último, que la lección permanente de esta poesía es la superación quelleva a efecto del sentimiento individualista, superación consumada de una vez para siempre" ${ }^{\prime 35}$. Poco antes, Concha ha señalado que "hay una total correspondencia entre la poesía de Neruda y su posición marxista. Energía poética y energía revolucionaria manan en él de una fuente única... a la cual es siempre fiel, en su canto y en su acción. No hay, pues, en absoluto, transformación mecánica de su poetizar por efectos de una militancia pretendidamente exterior" ${ }^{\prime \prime}$.

Sin embargo, en el interior mismo de la construcción a primera vista sólida de "Alturas de M acchu-Picchu" - que la mayoría de los críticos ven escindida en dos momentos: el de una mirada críticamente retrospectiva del poeta respecto a su pasado hasta el momento de la revelación y el de la representación del ascenso y descubrimiento del ser social y americano-, la superficie aparentemente homogénea de la escritura se ve hendida por la emergencia detrozos queinterrumpen inquietantementela continuidad del mensaje, introduciendo incertidumbre sobre la validez irrestringida de la verdad revelada acerca de la superación absoluta del individuo, su vida y su muerte.

Uno de estos fragmentos: el VII -que parece ser más bien un segmento esencial de la argumentación del poeta, que quiere ser un momento decisivo de ella, pero que, a mi juicio, se encuentra lastrado por la insuficiencia 0 ambigüedad desu (no) fundamento esencial- proclama, con solemnidad y dramatismo, el acaecimiento violento de la verdadera muerte, la muertehistórica, sobre la comunidad incásica:

33. Concha, op. cit., p. 132.

34]. Concha, op. cit., p. 135.

35. Concha, op. cit., p. 138. Por cierto, la idea de la superación de la muerte personal en la identidad colectiva no se desprende del fragmento citado, sino del ensayo en su totalidad.

36. Concha, op. cit., p. 138. 
Muertos de un solo abismo, sombras de una hondonada,

La profunda, es así como al tamaño

De vuestra magnitud

Vino la verdadera, la más abrasadora

Muerte y desde las rocas taladrada,

Desde los capiteles escarlata,

Desde los acueductos escalares

Os desplomasteis como en un otoño

En una sola muerte.

Hoy el aire vacío ya no llora,

Ya no conoce vuestros pies de arcilla,

Ya olvidó vuestros cántaros que filtraban el cielo

Cuando lo derramaban los cuchillos del rayo,

Y el árbol poderoso fue comido

Por la niebla, y cortado por la racha.

El sostuvo una mano que cayó de repente

Desde la altura hasta el final del tiempo.

Ya no sois, menos de araña, débiles

Hebras, tela enmarañada:

Cuanto fuisteis cayó: costumbres, sílabas

Raídas, máscaras de luz deslumbradora ${ }^{37}$.

Todavía más deslumbrantes son las secuencias en que el poeta describe la ciudadela como el depósito material en que se han inscrito las huellas de su habitación desaparecida y del paso del tiempo, las que el poeta descifra para - por mediación de su palabra- recuperar esa vida en imágenes y rearticularlas en la construcción de una conciencia americana que busca su realización en la lucha por una sociedad humanamente más justa.

No obstante, el extenso poema -al margen de su logrado pathos y sus poderosas fuerzas expresivas- termina atravesado por cierta discontinua ambigüedad. En el canto XII, el último, no cabe duda de que los habitantes de Macchu-Picchu están muertos para siempre, pero el poeta los resucita profanamente en imagen, recupera su memoria histórica para la lucha del presente y, así, los integra como una motivación más, en el presente de América, para aglutinar a los individuos en la praxis política como miembros de una misma colectividad inmersa en la lucha. Pero la escritura nerudiana no siempresigueel camino del programa impuesto por la voluntad y la ideología del poeta, dejándose desviar o más bien llevar por otras inclinaciones o sucumbiendo intermitentemente a otras solicitaciones aún más poderosas. Así, vuelve a mostrar como un dilema irresuelto lo que el programa doctrinal presentaba como una superación de las antiguas angustias del individuo:

${ }^{37}$ P. Neruda, "Alturas de M acchu-Picchu", en O.C., pp. 317-318.

61 
Amor, amor no toques la frontera

$\mathrm{Ni}$ adores la cabeza sumergida:

Deja que el tiempo cumpla su estatura

En su salón de manantiales rotos ${ }^{38}$.

Límites que-como en un poema de $M$ athias Claudius, en quela muerte alza el martillo en una cámara oscura- reaparecen aquí, a plena luz en la inmensidad del espacio, en que un cóndor marca con su sombra, grave, lentamente móvil, la presencia del tiempo en el reloj de piedra de la ciudadela incásica:

Y en el Reloj la sombra sanguinaria

Del cóndor cruza como una nave negra ${ }^{39}$.

***

También en la serie de odas elementales (1954-1957) -en pleno esfuerzo de disolución del yo privado del poeta en el yo colectivo, de instalación del sujeto poético en su dimensión social que coincide con la de todos, de voluntad de transparencia, de entrega a la felicidad y a los problemas de los otros, atento a los deberes políticos del poeta- reaparecen inesperadamente perturbaciones que pertenecen propiamente al yo anterior, al individuo alienado, desarticulado en la sociedad y en la natural eza y que, pese al acto desuperación eintegración en el ser social, parecerían no haber desaparecido del todo en este sujeto transformado. Atisbos de dimensiones inquietantes dela realidad tienen lugar, con cierta intermitencia, a lo largo de las odas.

Ya entre las primeras, en "O da a la claridad", el poeta -cuya tarea es "iluminar rincones", "destruyendo la oscuridad"- accede, a plena luz de día y después de una tormenta, al tacto y sinestésicamente a la visión y al gusto (acaso a la audición) del mar:

Toco

El agua marina.

Sabor de fuego verde,

De beso ancho y amargo

Tienen las nuevas olas

De este día 40 .

Las olas se suceden, se despliegan y repliegan, estallan en las rocas o mueren en la arena, su movimiento arma y desarma la forma de sus ondas,

${ }^{38}$ P. Neruda, id. O.C., p. 319.

${ }^{39}$ P. Neruda, id. O.C., p. 320.

${ }^{40}$ P. Neruda, "O da a la claridad", O das elementales, O.C., p. 967. 
exhiben su poderío y su derrota, son aguas de fuego - oximoron de sus contradictorios efectos- y tienen también, lo que es decisivo, un sabor amargo de larga data en la experiencia del poeta, que nos retrotrae hasta el "mar amargo que huye detrás del buque" de Residencia en la Tierra, "y sus dientes de sal volando en gotas" y, luego, nos proyecta sobre "la verdad es amargo movimiento" de "Fin de fiesta" en Cantos ceremoniales (1961).

En la misma oda - pese a la voluntad del poeta de aclarar todo- no puede menos que percibir la diferencia instalada en la transparencia de la luz:

La claridad sombría

Del manantial quellega ${ }^{41}$.

Bastante más adelante -en la apretada sucesión de odas que Neruda publica en la década del 50- se asoma a la superficie de las aguas del mar la red flotante y azotada de las al gas, que resisten los embates y a la vez azotan a las aguas mismas, que parecen renovar incesantemente su furia destructiva:

A veces
Las altas
Olas
Traen
En la palma
Deuna
Gran mano verde
Un tejido
Tembloroso:
La tela
Inacabable
Delas algas.
Son
Los enlutados
Guantes
Del océano,
Manos de ahogados
Ropa
Funeraria42.

El poeta ódico las representa como "enlutados guantes del océano" y ya en esta imagen -a pesar de su voluntad de dar forma (guante) a la relación en que el contenido, las aguas, imaginadas como manos de agua y de muertos, exceden infinitamente su agitado continente- nos trasmiten la desazón

42P. Neruda, “O das a las algas del océano", Tercer libro de odas, en 0.C., 1299-1300. 


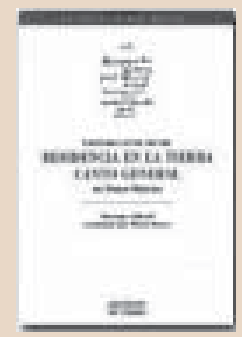

que produce la manifestación fúnebre en la superficie y en las profundidades: son "manos de ahogados" que retornan a la superficie como restos 0 pedazos de cuerpos al guna vez vivos. Pero la intención antropomórfica que ordena la relación aparentemente desordenada de las olas y las capas de algas, no logra, a mi juicio, controlar las energías dispersivas, centrífugas, creadoras, disolventes que allí se desatan y fraguan.

El resto de los versos que contienen la larga frase, y que concluye esta estrofa, recupera - desde "Io alto / del muro de la ola"- la dimensión positiva, germinal, incluso festiva de las propias algas y las aguas del mar.

Sin embargo, la oda finaliza en una paradójica síntesis de efectos sinestésicos, detacto escal ofríante-una disimulada, elegantealegoría de una contradicción que no exige ser resuelta, ya que la vida y la muerte aparecen interdependientes, la una (no) sosteniendo a la otra-, en que el poeta se corona, no con los laureles de la antigüedad, sino con

\section{Los pámpanos mojados \\ Del océano, \\ La cabellera muerta \\ Dela ola ${ }^{43}$.}

$* * *$

Al aparecer las 0 das elementales en 1954, Alone saludó alborozado una nueva etapa de la poesía nerudiana, ausente de oscuridades y tristeza (la etapa de Residencia en la Tierra), pero también de rencores y consignas (la etapa de Canto general): “... nunca N eruda había sonreído como ahora... Afirman que esta claridad se la impuso el Soviet para que llegue al pueblo... porque Neruda claro y alegre resulta infinitamente superior $y$, sobre todo - cosa poco marxista-, resulta libre, como si lo hubieran desatado y ya no marchara con aquel peso" 44 . La visión marxista del mundo habría "desaparecido, caído o volado como una vestidura", siendo reemplazada por "la salida al aire universal, fresco y ampliamenterespirable" ${ }^{\prime \prime 5}$. Convencido dela "M uerte y transfiguración de Pablo Neruda", en otro artículo, escrito algunos años después, Alone declara que su poesía "cada vez más abeja de oro, luminosa y desprendida, abandona la casa donde las telarañas lo envolvían, condenado a monótona sombra"46.

Contra la opinión de Alone -que no percibía otra dimensión política que la comunicada por la poesía políticamente explícita, portadora de con-

${ }^{43}$ P. Neruda, id. en O.C., p. 1.302.

${ }^{44}$ Alone (Hernán Díaz Arrieta), "Muertey transfiguración dePablo Neruda", El M ercurio, Santiago (30.01.1955).

${ }^{45}$ Alone, Id.

${ }^{46} \mathrm{Alone}$, "Oda a la tipografía”, Zig-Zag, Santiago (22.11.1956), p. 55. 
signas, es decir, aquel tipo de poesía de servicio que, por ejemplo, representaban Las uvas y el viento, publicadas el mismo año que las 0 das elementales- creo que en los momentos más logrados de la escritura de las odas, Neruda al canza una poesía de gran eficacia política, precisamente porque parece, a primera vista, pura poesía de celebración del mundo, sus materias, sus oficios, aunque a veces, o más bien bastante a menudo, se traslada de tema en una misma oda celebratoria, expresando preocupaciones, problemas, injusticias, aunque ya no en el tono iracundo o de admonición que acostumbraba antes, sino de comunicación o exhortación solidaria, de disimulado o explícito espíritu de clase en busca de justicia y un futuro mejor para todos, no sólo los desposeídos. Pues incluso la disposición gozosa, abierta a lo positivo del mundo, se funda no sólo en el bienestar personal a que, según muchos, habría llegado Neruda, sino también en la absoluta seguridad quetieneel poeta del advenimiento de un futuro de justicia social. En la "O da al aire" (justamente una de las celebradas por Alone) todavía aparece enunciado como esperanza fundada:

Ya vendrá un mañana

En que libertaremos

La luz y el agua,

La tierra, el hombre,

Y todo para todos

Será... ${ }^{47}$.

La misma esperanza, pero puesta como meta segura, en "O da a la claridad":

\author{
... Yo debo \\ repartirme \\ hasta que todo sea día, \\ hasta que todo sea claridad \\ y alegría en la tierra ${ }^{48}$.
}

Y más adelante, le dice - fraternal, más bien paternalmente, con la convicción de quien se funda en las leyes del desarrollo objetivo de la historia y quisiera ahorrarle al "hombre sencillo" sufrimientos por sus dudas en el cumplimiento de la llegada de ese momento- a su prójimo:

No sufras,

Ven conmigo

Porque aunque no lo sepas,

Eso yo sí lo sé:

47P. Neruda, "O da al aire", O das elementales, en O.C., p. 943.

48. N Neruda, "O da a la claridad", O das el ementales, en O.C., p. 968. 
Yo sé hacia dónde vamos,

Y es ésta la palabra:

No sufras porque ganaremos

Ganaremos nosotros

Los más sencillos,

Ganaremos,

Aunque tú no lo creas,

Ganaremos ${ }^{49}$.

Es tal la certeza de este desarrollo hacia el comunismo final que hasta la naturaleza - dela queel poeta se hace intérprete cósmico- lo manifiesta con sus signos:

\author{
M ientras tanto, \\ Nosotros, \\ Los hombres, \\ Junto al agua, \\ Luchando \\ Y esperando \\ Junto al mar \\ Esperando. \\ Las olas dicen a la costa firme: \\ "Todo será cumplido"50.
}

Esta poesía casi no impone consignas ni mandatos y tampoco propone temples heroicos o grandes sacrificios. El poeta no llama directamente al combate a la vista de un paisaje urbano degradado, de fábricas o enclaves mineros en quela explotación de los obreros se hace evidente, de campesinos famélicos y maltratados, sino que, simplemente, desdeun punto de vista que ama la vida y desde cierto bienestar, desde una felicidad que el poeta dice querer compartir, alaba el trabajo, las materias, los bienes del mundo, limitándose a desear para todos una sociedad más justa, dejando discretamente en un trasfondo apenas visi ble que, según su doctrina, es la lucha de clases la que permite alcanzar esta nueva sociedad.

La fluidez, transparencia y sencillez - bastante aparente a veces, más bien la difícil sencillez- de la escritura y la disposición bondadosa, sonriente, amante de la vida, de una vida plena para todos, sin conflictos evitables, el despliegue del aspecto socialmente positivo de las materias y los oficios, son al gunos de los medios con que estas odas comunican, de modo aparentemente inmediato, sus contenidos, incluido su sustrato político, leve, apenas discernible de su envoltura social, pero silenciosa y lentamente subversivo.

${ }^{49}$ P. Neruda, "O da al hombre sencillo", O das elementales, en O.C., p. 1.010.

${ }^{50}$ P. Neruda, “O da a la esperanza”, O das elementales, en O.C., p. 998. 
Encaminados en esta dirección de despliegue de la dimensión social de los seres, objetos, materias, actividades, sentimientos, etc., los diversos libros de odas parecieran llevar a cabo un proyecto poético que hace pensar en la Enciclopedia o Diccionario razonado de Ciencias, Artes y O ficios que se publicó de 1751 a 1766, bajo la dirección de Diderot y D'Alembert. Como los artículos en ella, las odas están, en cada volumen, ordenadas alfabéticamente, dela $\mathrm{A}$ a la Z, aunque los temas que las componen dependen más de las circunstancias del poeta, de la oportunidad, que de un proyecto sistemático y previamente organizado que pretendiera abarcar, en lo posible, la totalidad del saber y de la realidad en ese entonces, que era el caso de la Enciclopedia. Pero tal como la Enciclopedia había entregado un compendio del saber de eseentonces, a fin de colaborar en el progreso dela nueva sociedad, el poeta de las odas despliega los elementos y su utilidad social en la creencia de que - con la consolidación de la Unión Soviética y la realización de los planes quinquenales- ya estaba en marcha el cambio histórico que conduciría a una nueva humanidad. Desde luego, el punto de vista festivo y con frecuencia irónico del poeta nerudiano descarta cualquier pretensión dealcanzar una totalidad. Siente más bien que la realidad es pormenorizadamente inabarcable y, en este sentido, se contenta o complace en desplegar el contenido social de los temas que se le van apareciendo en el curso de los días, que adquirirían un carácter ejemplar.

Por ello, las odas quieren desplegar convincentemente una visión del mundo (sabiendo que la multiplicidad del mundo es inabarcable), esto es, educar para la nueva sociedad planetaria queel poeta avizora en el horizonte más o menos cercano (proximidad que iba a ser dolorosamente negada por el poeta en la etapa tardía de su producción).

De este modo más indirecto -y portando el contenido político como dimensión intrínseca de las imágenes desplegadas- las odas resultan más persuasivas políticamente que la poesía de denuncia directa, que comunica consignas para las que las imágenes son un ejemplo puramente exterior $y$, por tanto, poco convincente. En este sentido, la velada carga política -no la carga ideológica agregada por el sujeto únicamente comprometido- correspondea una visión del ser social queno excluyey mucho menos "supera" su temporalidad, sino que, al revés, la presupone, la exige. El sujeto comprometido está superpuesto - 0 antepuesto- a su existencia fragmentarizada y adopta la apariencia de ser absoluto y excluyente, producto de la "superación dialéctica" del mero individuo.

$* * *$

También Alain Sicard -en una serie de trabajos en querevisa autocríticamente al gunas interpretaciones suyas anteriores y procura reacondicionarlas para una lectura más actual de Neruda, liberada de al gunos prejuicios que 
parecían, en años anteriores, conceptos fundamentales, evidencias básicasconsidera que cierto tipo de poesía nerudiana de denuncia política que respondía a necesidades urgentes, la que el mismo crítico llama "poesía de circunstancia, no representa... el estrato más profundo dela relación entre poesía y política en la obra del poeta chileno"51.

Para entender esta relación más profunda -continúa diciendo Sicard"es preciso ensanchar nuestro campo de reflexión como el propio proyecto nerudiano nos invita a hacer" 52.

Pienso que no parece necesario discutir en este punto la afirmación de que la escritura de N eruda haya sido presidida, casi teleológicamente, por un proyecto unitario previo -cuyo propósito era realizar la "utopía totalizante" - que se habría mantenido relativamente inalterado durante toda la producción del poeta.

Para los problemas que ahora nos preocupan -que tienen que ver con la dimensión política y la representación de la historia y el ser humano en la poesía nerudiana- basta tomar en cuenta la distinción que introduceSicard, dentro de este proyecto, entre una poética y visión diurna y una poética y visión nocturna, que Neruda habría desarrollado separadamente, pero que se entrelazan, haciendo sentir o no sus efectos la una sobre la otra.

La poesía directamente política, de combate, dogmática - portadora de la ideología del socialismo real- sería sólo una parte de la poesía diurna que afirma la prioridad del ser social, quehaceal poeta asumir deberes sociales en la poesía, esto es, somete "a la estética a las exigencias éticas de la acción", que procura alcanzar un máximo de transparencia y capacidad comunicativa "escribo para el pueblo aunque no pueda leer mi poesía con sus ojos rurales"53- y que, por último, comprendea la poesía como un trabajo inserto dentro de la división social del trabajo. Para Sicard, "Io que queda exorcizado en esta versión nerudiana del vade retro es, desde luego, el viejo hombre y el canto egoístamente personal, pero más profundamente, es el maleficio personal"54.

Por otra parte, el sujeto de la visión nocturna -en especial, a partir dela crisis del social ismo real, queseinicia con las denuncias contra el stalinismo desde 1956- se retrotrae a la soledad y a una disposición o "gesto de autodisolución del sujeto dentro del mundo objetivo... de regresión a lo indiferen-

${ }^{51} \mathrm{~A}$. Sicard, "Poesía y política en la obra de Pablo Neruda", Revista Canadiense de Estudios H ispanoamericanos, XV, 3 (1991), p. 557. El propio Neruda en el prefacio al ncitación al nixonicidio y Alabanza de la Revolución Chilena, Santiago, Quimantú, 1973, declara que“... contra los enemigos de mi pueblo mi canción es ofensiva y dura como piedra araucana. Esta puedeser una función efímera. Pero la cumplo. Y recurro a las armas más antiguas de la poesía, al canto y al panfleto usados por los clásicos y los románticos y destinados a la destrucción del enemigo".

${ }^{52}$ A. Sicard, id., p. 557.

${ }^{53}$ P. Neruda, "Yo soy", Canto general, en O.C., p. 668.

${ }^{54} \mathrm{~A}$. Sicard, "Pablo Neruda: A plena luz camino por la sombra", en N. Ponce (ed.), Lectures d'une oeuvre, Paris, Eds. du Temps, 2001, p. 9. 
ciado" 55 , retomando la comprensión de sí mismo como un "carpintero ciego" y "sin manos" ${ }^{56}$ que elabora oscuramente una poesía que no se alcanza sólo con el trabajo de al guien que sabe hacer bien su oficio.

Sicard afirma que la visión diurna "genera, por decirlo así, naturalmente la antítesis como exigencia de su propio desarrollo", de la cual emergerían por lo menos dos puntos de apoyo para la rectificación dela visión diurna y los deberes que conlleva: uno, en el último canto de "Alturas de M acchuPicchu", en que la inmersión "inesperada" (así la califica inesperadamente Sicard) del sujeto en las ruinas descifraría "el secreto dela continuidad en la historia" y otro - luego de la crisis ideológica a mediados de los años 50 -que no es el período nerudiano que estudiamos aquí- en queel poeta nocturno propondría, como medio de "salvación" o superación de los errores y desviaciones del socialismo real, el "deber de ruptura", a fin de establecer o más bien decretar un día cero, "donde el fin coincide con el comienzo y donde el tiempo histórico realiza su renovación" 57.

Aunque la continuidad de este paralelismo y, sobre todo, su estatuto (palabra que Sicard usa, así como régimen, especificidad estética o dialéctica objetiva) no quedan nada de claras, creo que formalmente, al menos en partes considerables - las que corresponden a la poesía dogmática o ideológica-, ambos tipos depoesía parecen más bien incompatibles: no sólo se oponeun camino y discurso presidido por la ideología a una escritura poética de indagación, sino que, por una parte, el dogmatismo canalizado por la poesía diurna no está dispuesto a la apertura necesaria a toda inteligencia que conoce los límites de su conocimiento, ya que es autoritario y excluyente por principio. Por otra, tanto la poesía emocional mente voluntarista como la poesía dogmática - que no serían la totalidad de la poesía diurna- oponen a la poe sía nocturna o bien la pura afirmación de un sentimiento que no siempre alcanza a representar su objeto, o bien la práctica de la poesía como medio de comunicación de contenidos ideológicos anteriores a la propia elaboración dela escritura poética. Así, para nadiesería demasiado misteriosa la incompatibilidad entre los hallazgos de la indagación poética y la aplicación sólo en apariencia transparente de consignas, ideas e imágenes inmovilizadoras que reducen las capacidades significantes de la escritura, recubriendo el esfuerzo (des) constructivo de ella.

Creo que la fascinación por la simetría y la construcción de sistemas o una nostalgia todavía no desactivada - a pesar de su desconfianza ante algunos de sus anteriores supuestos y evidencias- han hecho deslizarse los últimos y valiosos estudios de Sicard a síntesis apresuradas, inseguramente

\footnotetext{
${ }^{55} \mathrm{~A}$. Sicard, id., p. 13.

${ }^{56} \mathrm{P}$. N eruda, "Yo soy", Canto general, en 0.C., p. 663. Cf. "Sonata y destrucciones" deResidencia en la Tierra.

${ }^{57} \mathrm{~A}$. Sicard, id., p. 16.
} 
totalizantes que, para su desgracia, inhiben la productividad crítica dealgunas de sus proposiciones, entre ellas, la separación de dos niveles en la poesía nerudiana, asignando a la poética nocturna las indagaciones marcadas por el "maleficio temporal" (como llama el crítico a lo que, grosso modo, sería el (no) fundamento a que accede el poeta y (no) acepta en los poemas de Residencia en la Tierra, 1935, en un extremo y en los de M emorial deIsla Negra, 1964, en el otro). Pero sería justamente en este nivel "profundo" que estaría - para Sicard- integrada la dimensión política del hombre, por ser lo político esencial a la experiencia humana, lo que le lleva a advertir -contra la persistencia en su trabajo de pretensiones totalizantes- quela poesía "tienela ventaja sobrelas ideologías ... [ detener] una capacidad relativizadorae interrogante, que es el mejor antídoto contra la osificación de la verdad en dogma"58.

A estas alturas de este estudio me parece admisible pensar que el desarrollo de la poesía de N eruda no se modifica sustancialmente, hacia 1936, sólo por una súbita conversión poética -como lo afirmó Amado Alonso-, resultando, por el contrario, más productiva la proposición de Loyola, deque en la base de estecambio seencuentra la convergencia escalonada de una serie demotivaciones personales y de los diversos contextos en queestaba inserta la actividad poética nerudiana. Para Loyola, junto al indudabley decisivo efecto de la Guerra Civil española y el asesinato de Federico García Lorca para el desarrollo dela poesía deNeruda en esos conflictivos años-orientada haciala llamada poesía de compromiso político, a la que habían adherido muchos intelectuales ante la amenaza fascista- habría también que mencionar, por ejemplo, como se ha dicho antes, los alcances que tuvo el viaje realizado por el poeta, hacia 1938, a su lugar deorigen para trasladar los restos desu padre a la sepultura de su madrastra, fallecida poco después de éste. "La copa de sangre" - publicada tardíamente en 1943- da testimonio del sentimiento de profunda pertenencia a esa tierra que despertó esteretorno inesperado en el poeta, el cual sería una de las motivacionesque dio origen al proyecto de un Canto general de Chile que, como se sabe, a medida que iba avanzando, terminó por transformarse en un Canto general de América, su historia y geografía.

Como lo expresa el poeta hacia 1954: "Comencé entonces a pensar no sólo en la poesía social. Sentí que estaba en deuda con mi país y con mi pueblo... Muy pronto me sentí complicado, porque las raíces de todos los

${ }^{58} \mathrm{~A}$. Sicard, "Poesía y política en la obra de Pablo Neruda", Revista Canadiense de Estudios Hispánicos, XV, 3 (1991), p. 561. 
chilenos se extendían debajo de la tierra y salían en otros territorios" 59 . Por esos mismos años, visita las ruinas dela ciudad perdida delos incas, M acchuPicchu, y recuerda-en el mismo texto citado antes-: "Ya no pude segregarme de aquellas construcciones. Comprendía que si pisábamos la misma tierra hereditaria, teníamos al go que ver con aquellos al tos esfuerzos de la comunidad americana, queno podíamosignorarlos, quenuestro desconocimiento o silencio era no sólo un crimen, sino la continuación de una derrota... Penséen el antiguo hombre americano. Vi sus antiguas luchas enlazadas con las luchas actuales. Allí comenzó a germinar mi idea de un Canto general americano... Aquella visita cambió la perspectiva. Ahora veía a América entera desde las alturas de M acchu-Picchu, con mi nueva concepción"60. La exigencia que hace Loyola de una "aproximación realista a la historia que se exhibe, en su práctica crítica, como un reconocimiento de leyes objetivas de la historia y su afirmación de un "sentimiento objetivo de la muerte" que se alcanza en la integración en el ser social o colectivo, restando el individuo como un desecho de la alienación, en suma, "el triunfo definitivo y la superación de la muerte en la continuidad de la lucha popular" bastarían para desestimar o encontrar críticamente inaceptable la chatarra ideológica que este especialista - un destacado especialista, como se sabe- amontona abusivamente encima de los poemas nerudianos, tapiando su capacidad significante y la complejidad de sus si gnificaciones y referencias. También "Ia conciencia histórica de lo americano" que Loyola postula y luego legitima debe más a las declaraciones contingentemente partidarias de N eruda 0 al contenido meramente ideológico de algunos poemas que a otros niveles de su escritura de esos años en que, pese a la represión ideológica y a la autocensura, logran emerger aún sus hallazgos respecto a la historia y al ser humano ${ }^{61}$.

***

Por el contrario, las distinciones de varios niveles de significación y de disposición del sujeto "diurno" y "nocturno" - que hace Sicard- tendrían que conducir a que se exhiban las tensiones irresueltas, o falsamente resueltas, entre el impulso a la representación totalizante y la emergencia fragmentada de los correlatos o entre la experiencia de la temporalidad como límite y su supuesta superación desde "Reunión bajo las nuevas banderas" en adelante. Pero es la tendencia a la totalización y a cierta sistematicidad - aún soterradamente activas en el crítico- la que le impide detenerse en el des-

${ }^{59}$ P. Neruda, "Algo sobre mi poesía y mi vida”, Aurora, Santiago, 1 (julio de 1954). Citado de Liberación, 1 (1980), p. 15.

${ }^{60}$ P. Neruda, id., p. 16.

${ }^{61}$ Conciencia histórica de lo americano que está expuesta en el capítulo referido a los años 1937-1945, pp. 163-242 de su Ser y morir en Pablo Neruda, ya citado. 
pliegue o examen del correlato de sus hallazgos, la que lo empuja a la clausura de esta posibilidad deaprehender las diferencias de lo que(no) aparece y a sustituirlas por sucedáneos sostenidos y empapados por la ideología. La apoteosis de esta concepción teleológica y "objetiva" de la historia -que ya en esos años no podía disimular su consistencia de cartón piedra- se al canza en el más resistido libro de Pablo Neruda, en Las uvas y el viento (1954), envolviendo incluso a la naturaleza en el ámbito desu dominio. Así, la muerte de Stalin es silenciosamente comunicada a un humilde pescador de las lejanas costas de Chile que ha caído en la mira del poeta:

Camarada Stalin, yo estaba junto al mar en Ia Isla Negra

Descansando de luchas y viajes,

Cuando la noticia de tu muerte llegó como un golpe de océano.

Fue primero el silencio, el estupor de las cosas,

y luego llegó del mar una Ola grande.

De algas, metales y hombres, piedras, espuma y

Lágrimas estaba hecha esta ola (...)

... M ás tarde el pescador de erizos, el viejo buzo y poeta,

Gonzalito, se acercó a acompañarme bajo la bandera.

"Era más sabio que todos los hombres juntos", me dijo

mirando el mar con sus viejos ojos, con los viejos ojos del pueblo.

... "Pero M alenkov ahora continuará su obra”, prosiguió

Levantándose el pobre pescador de chaqueta raída.

Yo lo miré sorprendido pensando: Cómo. Cómo lo sabe?

De dónde, en esta costa solitaria?

Y comprendí que el mar se lo había enseñado ${ }^{62}$.

Sorprende que Neruda no haya defendido Las uvas y el viento sólo en los años más álgidos de la Guerra Fría, sino también mucho después, cuando era ya evidente que los hechos no realizaban las predicciones, lo queN eruda también había percibido y, todavía más, no había dejado de reconocer desde cierta actitud cautelosamente crítica y desolada. En las M emorias, declara que cree que "tanto Residencia en la Tierra, libro sombrío y esencial dentro demi obra, como Lasuvasy el viento, libro de grandes espacios y muchaluz, tienen derecho a existir en alguna parte. Y no me contradigo al decir esto". Acto seguido, confiesa: “La verdad es que tengo cierta predilección por Las uvasy el viento, tal vez por ser mi libro más incomprendido; o porqueatravés de sus páginas yo me eché a andar por el mundo. Tiene polvo de caminos y agua de ríos; tiene seres, continuidad y ultramar de otros sitios que yo no conocía y que me fueron revelados de tanto andar. Es uno de los libros que más quiero, repito"63.

62P. Neruda, "En su muerte", Las uvas y el viento, en O.C., p. 762.

${ }^{63}$ P. Neruda, Confieso que he vivido, Barcelona, Seix Barral, 1974, p. 405. 
Este tipo de declaraciones y la persistencia en escribir poesía política o partidista o de servicio llevan, desde luego, a pensar queen Neruda coexistía, en un conflicto irresuelto, una disposición moral, voluntarista, sentimental y un fuerte impulso a la indagación poética, desligado de ese compromiso moral, que operaba en otro nivel, pero que, al emerger a la superficie, 0 antes, no dejaba de entrar en fuertes conflictos con él. Por supuesto -como he tratado demostrar- hay poemas deN eruda en quela dimensión política del ser humano está poéticamente comunicada, y no sólo agregada por una conciencia moral que quiere someter y dirigir (desviar) a la escritura poética. Habría que recordar que, para N ietzsche, "Ia lucha contra la finalidad en el arte es... una lucha contra la tendencia moralizante en el arte, contra su subordinación a la moral"64.

La representación altamente ideologizada de la realidad reaparece, previsiblemente, en las diversas colecciones de 0 das elementales, pero - como hemos visto- no es ya la única, a pesar de que el poeta, con mucha seguridad, proclame proféticamente:

Las olas dicen a la costa firme 'todo será cumplido'65.

No obstante, ya en los comienzos de este período emerge, como hemos también visto, en "Canto sobre unas ruinas" -en medio de la denuncia dela violencia destructora ejercitada contra el pueblo español- el melancólico reconocimiento de la fragilidad original de los fundamentos de toda obra humana, ya que, en última instancia, seapoyan en la huidiza (in)consistencia del tiempo. Por cierto, más de algún crítico de los años de la Guerra Fría afirmaría que se trata, en este caso, de la subsistencia residual de algunas ideas de la época residenciaria, en tránsito de superación y ya plenamente desaparecidas en Canto general o, más aún, en Lasuvasy el viento (lo queen este último libro no sería ningún mérito), pero parece más ajustado al decurso de la poesía nerudiana pensar que esta fuerte sensación de la temporalidad de todo lo existentenunca habría abandonado al poeta, apareciendo incluso con otras modulaciones, históricamente decisivas, en su poesía del período final, póstumamente publicada.

En este sentido, quizás sea en las "Alturas de M acchu-Picchu" -y fragmentarizadamente en otros momentos de Canto general, cuyo imperativo de totalización quiere excluir toda experiencia que lo coloque en peligro, es decir, lo exceda- donde puededetectarsemás ejemplarmenteuna experiencia dela historia y la temporalidad anterior a la comprensión de ambas, ya traspasada de ideología, que asume explícitamente el poeta heroico, apoyándo-

${ }^{64} \mathrm{~F}$. N ietzsche, El crepúsculo de losídolos (1889), M adrid, Alianza, 1973, p. 101.

65P. Neruda, “O da a la esperanza”, O das elementales, O.C., p. 988. 
se en una base escindida, de materiales incompatibles: por una parte, en el descubrimiento de las raíces precolombinas del hombre americano, surgido de su lectura de las huellas depositadas en las ruinas incásicas por la naturaleza y por la historia; por otra parte -impulsado por su anhelo de justicia social, de pertenencia a una comunidad, por su doctrina y voluntad política- , esquematiza y recubre esa experiencia de descubrimiento con la rearticulación ideologica de un pasado aciago, marcado por la servidumbre y la destrucción veladamenteimperialista con un presentetambién aciago, pero ya combatiente, en que el poeta se hace portavoz de los oprimidos, convocando las fuerzas de la actualidad y la carga histórica del pasado para incitarlas a la lucha por la liberación política y la justicia social.

"Alturas de M acchu-Picchu" despliega una ambigüedad genérica que unida al innegable hermetismo de suficientes fragmentos diseminados a lo largo del poema- perturba la aprehensión fluida de alguna continuidad en los contenidos y en la disposición anímica del poeta. Externamente, el extenso poema parece una elegía, pero -como lo observó hace tiempo Cedomil Goic- sus partes, a saber, consideraciones sobre la muerte, lamentación y consolación, no se suceden, sino que se entrelazan sostenidas por temples de ánimo diversos o "confusos". Además, algunos fragmentos no cubren ni desarrollan sólo los contenidos y formas adscritas tradicional mente a la elegía (la consolación, por ejemplo, está recubierta o sustituida por una exhortación a la lucha, que sólo muy indirectamente se puede entender como consuelo, no ya para los que han muerto, sino para sus supuestos descendientes, los explotados de hoy que, reunidos a los anteriores por la mediación y la voz del poeta, tienen el consuelo de saber que los muertos serán redimidos por la lucha que ellos emprenderán para lograr la justicia so(ial) ${ }^{66}$.

Lo que sí parece evidente es que el extenso poema se constituye desde la revelación que tiene el poeta de su ser americano, de su raíz precolombina, originaria y diferencial. Y que es desde las fuerzas emanadas desde esta iluminación profana queel poeta conduceal poema en "una dirección del tiempo" que le permite abarcarlo y articularlo en una supraestructura que proyecta una comprensión tel eológica y mecánicamente dialéctica de la historia del ser humano.

Pero también parece evidente que esta supraestructura - que pretende recubrir la totalidad del extenso poema y darle unidad- está voluntarísticamente sobrepuesta a la serie de secuencias y - lo que es decisivo- legitimada por la pura ideología.

Con todo, no puede perderse de vista que es justamente-aunqueno sólo-

${ }^{66} \mathrm{C}$. Goic, "Alturas de M acchu-Picchu: la torre y el abismo", en Anales de la Universidad de Chile(1971), 153-167. 
en relación a esta modalidad de poesía políticamente comprometida y, desde luego, en relación a los acontecimientos históricos a que se refería, pero cuya realidad y decurso terminó por mostrársele al poeta en radical contraste con la representación ideológicamente tergiversada que había hecho de ellos, queN eruda elabora -a partir deEstravagario (1958) y M emorial de I sla Negra (1964)- los poemas de su etapa última, caracterizados por una disposición melancólica, pero también crítica y autocrítica en variable medida, poemas que se despliegan en un reiterado movimiento de retorno sobresu propio pasado autobiográfico y losacontecimientos históricos en que se vio involucrada, de modo activo o pasivo, su vida ${ }^{67}$.

En consecuencia con su concepción materialista de la vida -que es anterior a los poemas de este período y prácticamente correlativa de la obra nerudiana desde sus comienzos- la representación del individuo supone su desaparición completa con la muerte (aunque, como sabemos, la herencia de su trabajo, mayor o menor o nada, la recibe la comunidad a que pertenece). Esta muerte -como reintegración a la totalidad material y su poder germinador- está magistralmente expuesta en "O da a unas flores amarillas", en que el poderio arrollador del mar en movimiento no impide la aparición

Que estalla

Sobre la arena el oro

De una sola

Planta amarilla ${ }^{68}$.

Así:

$\mathrm{Ni}$ aire, ni fuego, ni agua

Sino tierra

Sólo tierra

Seremos

Y tal vez

Unas flores amarillas ${ }^{69}$.

Estemismo esplendor dela germinación ya se ha extinguido; en cambio, el efecto esterilizante desu ausencia está captado en una "oda al viejo poeta" que de la mano con la muerte llega hasta

Un desmantelado dormitorio

Y en él durmieran

${ }^{67}$ Estravagario es, como se sabe, el libro que da inicio a esta revisión crítica del pasado. Su tono es festivo, aparentemente superficial, pero no extraño a la disposición autocrítica. Vid. M i prólogo a la nueva edición de Estravagario en Ed. Sudamericana (2003).

${ }^{68}$ P. Neruda, Tercer libro de odas (1959), en O.C., p. 1.369.

${ }^{69}$ P. Neruda, id. 0.C., p. 1.369-1.370. 


Como dormiremos
Todos
Los
Hombres:
Con
Una rosa
Seca
En
Una
Mano
Que también cae
Convertida en polvo ${ }^{70}$.

En abierto contraste con la experiencia, a que se accede en Residencia en la Tierra, de la transitoriedad irrefrenable del lenguaje y la poesía, que sería "el testimonio extraño que sostengo / con eficiencia cruel y escrito en cenizas", cercano a los versos de Góngora escritos "en los anales diáfanos del viento", el poeta nerudiano de este período de poesía política - estableciendo una relación de complementariedad con la afirmación del ser social del hombre y, sin duda también, acogiéndose a la tradición milenaria sobre la inmortalidad de la poesía, que se remonta a Homero y a los líricos arcaicos como Tirteo o Teognis- comprende la poesía como un mensaje que va más allá de la vida y la muerte de su autor, instalándose en una especie de eternidad que, por supuesto, no es trascendental, pero podría denominarse"objetiva" y que extiende sus límites hasta los de una historia en expansión progresiva 0, todavía más, los hace coincidir con los límites de la humanidad misma. Así, agradece a la poesía:

\author{
Porque contigo \\ Mientras me fui gastando \\ Tú continuaste \\ Desarrollando tu frescura firme, \\ Tu ímpetu cristalino, \\ Como si el tiempo \\ Que poco a poco me convierte en tierra \\ Fuera a dejar corriendo eternamente \\ Las aguas de mi canto ${ }^{71}$.
}

70P. Neruda, "O da a un ramo de violetas", Tercer libro de odas, O.C., p. 1.425.

71P. Neruda, 0 das elementales, en O.C., pp. 1.077-1.078. Sobre la inmortalidad por la literatura, vid. E.R. Curtius," La poesía como inmortalización", en Literatura europea y Edad M edia Latina, M éxico, FCE,1955, pp. 683-700, W. Muschg, H istoria trágica de la literatura, M éxico, FCE, 1965, pp. 683-700. Sobre Tirteo y Teognis, F. R. Adrados (ed.), Líricos griegos. Elegíacos y yambógrafos arcaicos, Barcelona, Alma M ater, 1959. 
No es necesario retrotraerse a reflexiones como la de Schiller de que "el destino de una obra poética va unido al destino del lenguaje, el cual difícilmente permanecerá tal como es ahora" ni retroceder hasta la lección (todavía generosa en la imaginación de la catástrofe) de Quevedo ante las ruinas de Roma:

¡Oh Roma! En tu grandeza, en tu hermosura, huyó lo que era firme, y solamente lo fugitivo permanece y dura ${ }^{72}$.

Q uizás la última observación de este trabajo - dedicado al problema de la inexistente conversión poética de Neruda y al desarrollo de su poesía política- sea que el sentimiento de la necesidad de una reflexión poética que, entre otras fuerzas, impulsa la poesía última de Neruda no está motivado sólo por una revisión crítica de su posición y poemas políticamente comprometidos y su desajuste con los acontecimientos históricos, sino que esta reflexión pretende al canzar todas las dimensiones de una vida que ahora se le aparece fragmentarizada, sobre la base de un retorno a su experiencia profunda de la temporalidad, la materialidad y la historia, contenidas discontinuamentey en diversa medida a lo largo de su extensa obra. Creo que ésta es, poéticamente, la fuente última que mantiene su obra y las diversas dimensiones que ilumina con su claridad sombría.

Bibliografía

Adrados, F.R. (ed.). 1959. Líricos griegos. Elegíacos y yambógrafos arcaicos, Barcelona, Alma Mater.

Alone (Hernán Díaz Arrieta). 1955. “Muertey transfiguración de Pablo Neruda”, El M ercurio, Santiago (30.01.)

Alone(Hernán Díaz Arrieta). 1956. “O da a la tipografía”, Zig-Zag, Santiago (22.11.). Alonso, Amado. 1940. Poesía y estilo de Pablo Neruda, B. Aires, Ed. Sudamericana, 1966, 3 a ed.

Concha, Jaime. 1964. "El descubrimiento del pueblo en la poesía de Neruda", Aurora, Santiago, 3-4.

Curtius, E. R. 1955. “La poesía como inmortalización”, en Literatura europea y Edad Media latina, M éxico, FCE, pp. 683-700.

Diccionario Enciclopédico de las Letras de América Latina. 1988. Caracas, Biblioteca Ayacucho s.v. Neruda.

Goic, Cedomil. 1971. "Alturas de M acchu-Picchu: la torrey el abismo", en Anales de la Universidad de Chile, 153-167.

Loyola, Hernán. 1967. Ser y morir en Pablo Neruda, Santiago, Ed. Santiago.

${ }^{72} \mathrm{~F}$. de Quevedo, O bras completas, Barcelona, Planeta, 1981. Ed. J.M . Blecua, p. 261. 
Loyola, Hernán. 1971. "Pablo Neruda. Itinerario de una poesía", en P. Neruda, Antología esencial, B. Aires, Ed. Losada.

Muschg, W. 1965. Historia trágica de la literatura, M éxico, FCE.

Neruda, Pablo. 1954. “Algo sobre mi poesía y mi vida”, Aurora, Santiago, 1 (julio de). Citado de Liberación, 1 (1980).

Neruda, Pablo. 1962. O bras completas, B. Aires, Ed. Losada.

---------- . 1973. Incitación al nixonicidio y alabanza de la Revolución chilena, Santiago, Quimantú.

---_.-- . 1974. Confieso que he vivido, Barcelona, Seix Barral, p. 405.

----------- . 2003. Estravagario, Ed. Sudamericana.

Nietzsche, F. 1973. El crepúsculo de los ídolos (1889), M adrid, Alianza, p. 101.

Quevedo, F. de. 1981. O bras completas, Barcelona, Planeta, Ed. J. M . Blecua, p. 261. Rodríguez Fernández, M ario. 1964. "Reunión bajo las nuevas banderas", M apocho, Santiago, II, 3, pp. 238-248.

Sicard, A. 1991. "Poesía y política en la obra de Pablo Neruda", Revista Canadiense de Estudios Hispanoamericanos, XV, 3, p. 557.

Sicard, A. 2001. "Pablo Neruda: A plena luz camino por la sombra", en N. Ponce (ed.), Lectures d'une oeuvre, Paris, Eds. du Temps, p. 9. 